\title{
A NEW SPECIES OF THE PRODUCTID BRACHIOPOD Aseptella FROM THE LOWER CARBONIFEROUS OF THE CANTABRIAN MOUNTAINS (SPAIN)
}

\author{
Cor F. WINKLER PRINS' \& María Luisa MARTÍNEZ CHACÓN

\begin{abstract}
' Nationaal Natuurhistorisch Museum Naturalis, Postbus 9517, 2300 RA Leiden, The Netherlands. e-mail: winkler@naturalis.nnm.nl

2Dpto de Geología, Universidad de Oviedo, c/. Jesús Arias de Velasco, s/n, 33005 Oviedo, España. e-mail: mmchacon@asturias.geol.uniovi.es
\end{abstract}

\begin{abstract}
Winkler Prins, C.F. \& Martínez Chacón, M.L. 1998. A new species of the productid brachiopod Aseptella from the Lower Carboniferous of the Cantabrian Mountains (Spain). [Una nueva especie de Aseptella (braquiópodo, prodúctido) del Carbonífero Inferior de la Cordillera Cantábrica (España)]. Revista Española de Paleontología, 13 (2), 243-249. ISSN 0213-6937.
\end{abstract}

\begin{abstract}
A new species of Aseptella, A. beetsi, is described from Lower Carboniferous, Viséan (Arundian-Holkerian) to lower Namurian (Arnsbergian) griotte limestones of the Cantabrian Mountains, variously called Alba or Genicera Formation. The new species, with a weakly developed brachial median septum, seems to be the ancestor of the type species, A. asturica, from the Bashkirian of Cantabrian Mts, which only develops a median septum in its juvenile specimens. The new species shows a peculiar offshoot of the marginal ridge, possibly for better separation of the ears. The systematic position of the genus Aseptella is briefly discussed as are the implications of the occurrence of this genus in Argentina.
\end{abstract}

Keywords: Aseptella, Productida, Brachiopoda, Lower Carboniferous, Cantabrian Mountains, Spain.

\section{RESUMEN}

Se describe una nueva especie de Aseptella, A. beetsi, de la caliza griotte del Carbonífero Inferior de la Cordillera Cantábrica, llamada Formación Alba o Genicera. La edad del material varía entre el Viséense (Arundiense-Holkeriense) y el Namuriense inferior (Arnsbergiense). La nueva especie se caracteriza por presentar un débil septo medio en el interior de la valva braquial, carácter que la señala como probable antepasada de la especie tipo, A. asturica, del Bashkiriense de la Cordillera Cantábrica, en la que el septo medio se ha observado únicamente en algunos ejemplares juveniles. La nueva especie presenta también una peculiar ramificación de las crestas marginales que, posiblemente, mejoraría la separación de las orejetas. Se discute la posición sistemática del género Aseptella, y también las implicaciones de los hallazgos del género en Argentina.

Palabras clave: Aseptella, Productida, Brachiopoda, Carbonífero Inferior, Cordillera Cantábrica, España.

\section{INTRODUCTION}

A new species of Aseptella is described based on material collected from various levels of the Lower Carboniferous griotte limestones of the Cantabrian Mountains, variously called Alba Formation or Genicera Formation (Comte, 1959; Wagner et al., 1972; Sánchez de Posada et al., 1996), including a transitional horizon with the overlying black limestones of the Barcaliente Formation (see Figs. 1 and 2). The oldest specimens, of middle Viséan (Arundian-Holkerian) age, are found at Triollo, whilst the other specimens are of early Namurian (Arnsbergian) age.
This formation is exposed in steeply dipping thrust structures of various tectonic units in the Cantabrian Mountains (see Fig. 1).

Collecting was done by the authors, partly accompanied by Dr L.C. Sánchez de Posada. A rich collection from Perlora was obtained by the National Natuurhistorisch Museum at Leiden from the former Geological Institute of Leiden University (unfortunately the collector is unknown).

The material is deposited at the Geology Department of the University of Oviedo (prefixes DPO) and at the Nationaal Natuurhistorisch Museum Naturalis at Leiden (prefixes RGM). 


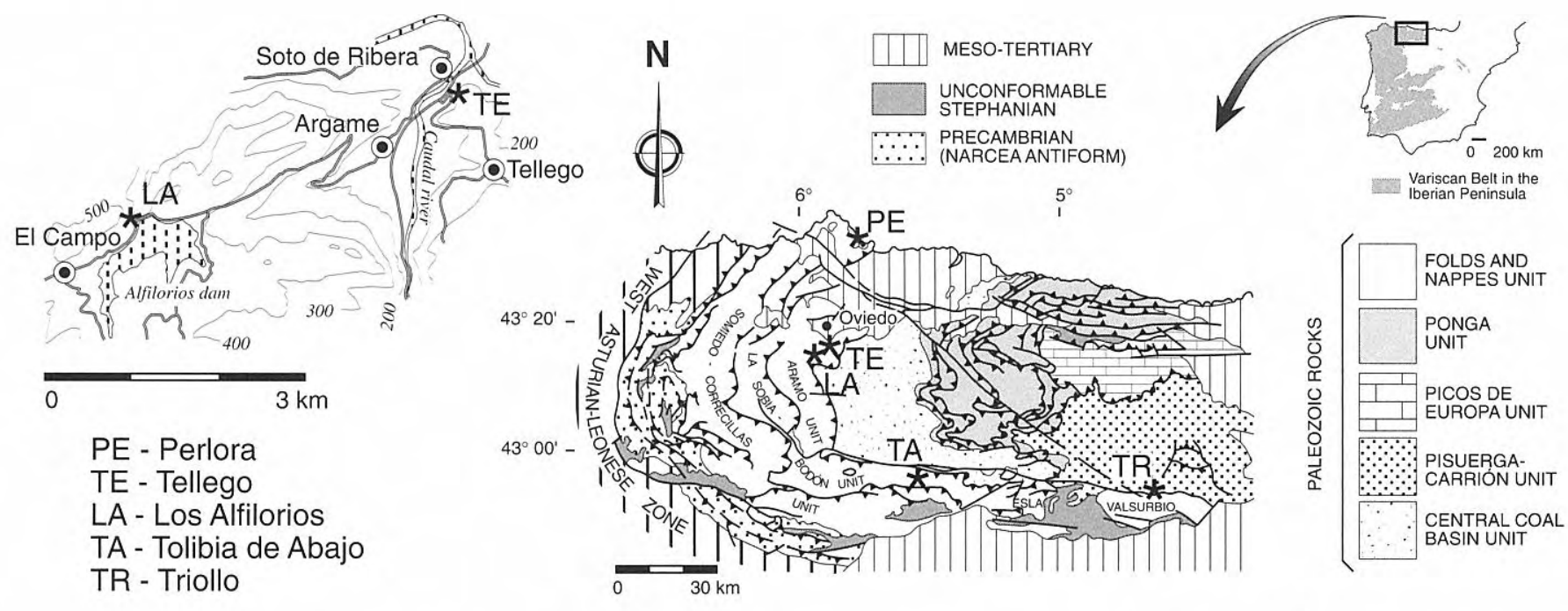

Figure 1. A: Location of collecting localities. Map of the Cantabrian Zone showing the main geological structures after Julivert (1971), modified by Pérez-Estaún et al. (1988). B: Los Alfilorios and Tellego localities. LA - Los Alfilorios; PE - Perlora; TA - Tolibia de Abajo; TE - Tellego; TR - Triollo.

\section{COLLECTING LOCALITIES}

\section{Triollo 1 (WP 89)}

A quarry in the red cherty shales of the Lavandera Member of the Genicera Formation (Wagner et al., 1972), situated c. $1200 \mathrm{~m} \mathrm{~S}$ of Triollo (Palencia) on the eastern side of the Camporredondo Reservoir (sheet 106 'Camporredondo de Alba' of the geological map of Spain 1:50.000, coordinates $42^{\circ} 54^{\prime} 40^{\prime \prime} \mathrm{N} \mathrm{4} 41^{\prime} \mathrm{W}$ ) (Figs. 1 and 2). The locality was first described by Gandl (1977, p. 125), who concluded to a middle Viséan age on his trilobite fauna (Pericyclus Zone $\partial$, i.e. Arundian-Holkerian) which corresponds with the information provided by the conodonts (bilineatus-delicatus Zone; see van Adrichem Boogaert, 1967, figs. 42, 50). On the western side of the reservoir, opposite the quarry (coordinates $42^{\circ} 54^{\prime} 40^{\prime \prime} \mathrm{N}$ $4^{\circ} 41$ ' $30^{\prime \prime} \mathrm{W}$ ), the same red cherty shales are exposed below the main road with the same faunas (WP 89A).

\section{Los Alfilorios (AL-1, AL-2)}

Local road from Soto de Ribera to Pedroveya; Los Alfilorios Reservoir, $1 \mathrm{~km} \mathrm{~W}$ of the village of La Carrera. Exposure along the service road for the dam installations (sheet 52 'Proaza' of the geological map of Spain 1:50.000, coordinates $43^{\circ} 17^{\prime} 48^{\prime \prime} \mathrm{N} 5^{\circ} 55^{\prime} 12^{\prime \prime} \mathrm{W}$; Asturias) (Figs. 1 and 2). From the reddish marls at the top of grey-beige limestone layers (AL-1) and at the base of overlying light grey limestones (AL-2) of the Canalón Member, immediately below the dark grey limestones of Barcaliente Formation. Normally the red layers are considered to be Viséan in age, whilst the grey layers are early Namurian (Kullmann, 1962), but we have no proof that this is here also the case. The fauna is considered to be of Arnsbergian age, although a Pendleian age cannot be excluded for the red material.

\section{Tellego (B-147)}

An exposure on the $\mathrm{N}$ side of the first bend of the local road to Tellego, c. $200 \mathrm{~m}$ from the road Oviedo-Mieres $(\mathrm{N}$ 630 ; sheet 52 'Proaza' of the geological map of Spain
1:50.000, coordinates $43^{\circ} 18^{\prime} 32^{\prime \prime} \mathrm{N} 5^{\circ} 52^{\prime} 28^{\prime \prime} \mathrm{W}$; Asturias) (Figs. 1 and 2). The fauna comes from greenish or beigecoloured marls on top of a cream-coloured limestone in the topmost part of the Canalón Member (on top of sample TE5 of Menéndez Álvarez, 1991, pp. 58-59, figs. 31-32) and is Arnsbergian in age.

\section{Perlora (PC-2)}

A large quarry of the company Tudela Veguin S.A., situated in the hamlet Nozaleda W of Perlora (sheet 14 'Gijon' of the geological map of Spain 1:50.000, coordinates $43^{\circ} 34^{\prime} 50^{\prime \prime} \mathrm{N} 5^{\circ} 46^{\prime} \mathrm{W}$; Asturias), has on its north side the top part of the griotte exposed. Geenish and reddish marls at c. $0.20 \mathrm{~m}$ below the base of the Barcaliente Formation contain an interesting fauna of brachiopods and ostracods. It is presumably the same level from which previously similar material had been collected (WP 82) and which has also provided a rich goniatite fauna to Kullmann, some trilobites and corals (see Gandl, 1977, p. 129).

\section{Tolibia de Abajo (WP 51)}

An exposure (small local quarry) situated c. $700 \mathrm{~m} \mathrm{~S}$ of Tolibia de Abajo (sheet 104 'Boñar' of the geological map of Spain 1:50.000, coordinates 42 $57^{\prime} 40^{\prime \prime} \mathrm{N} 5^{\circ} 24^{\prime} \mathrm{W}$; León), on the east bank of the River Curueño when leaving the gorge formed by the river in the Barcaliente and Valdeteja limestones of the Bodón thrust unit (Evers, 1967). The Aseptella, together with some chonetids, is found in a transitional layer below the Barcaliente Formation. On general grounds an Arnsbergian age is assumed, the same age as the underlying limestones of the top part of the Gorgera Member, which contain a rich goniatite fauna of the same age (Eumorphoceras Zone 2). It should be noted, however, that other goniatites collected by one of us (C.F.W.P.) and described by Kullmann (1962, pp. 11-12; 1963 , p. 314) as coming from Tolibia are not from this locality but from a locality $2 \mathrm{~km}$ to the south in the same structure (behind a small restaurant called La Venta). 


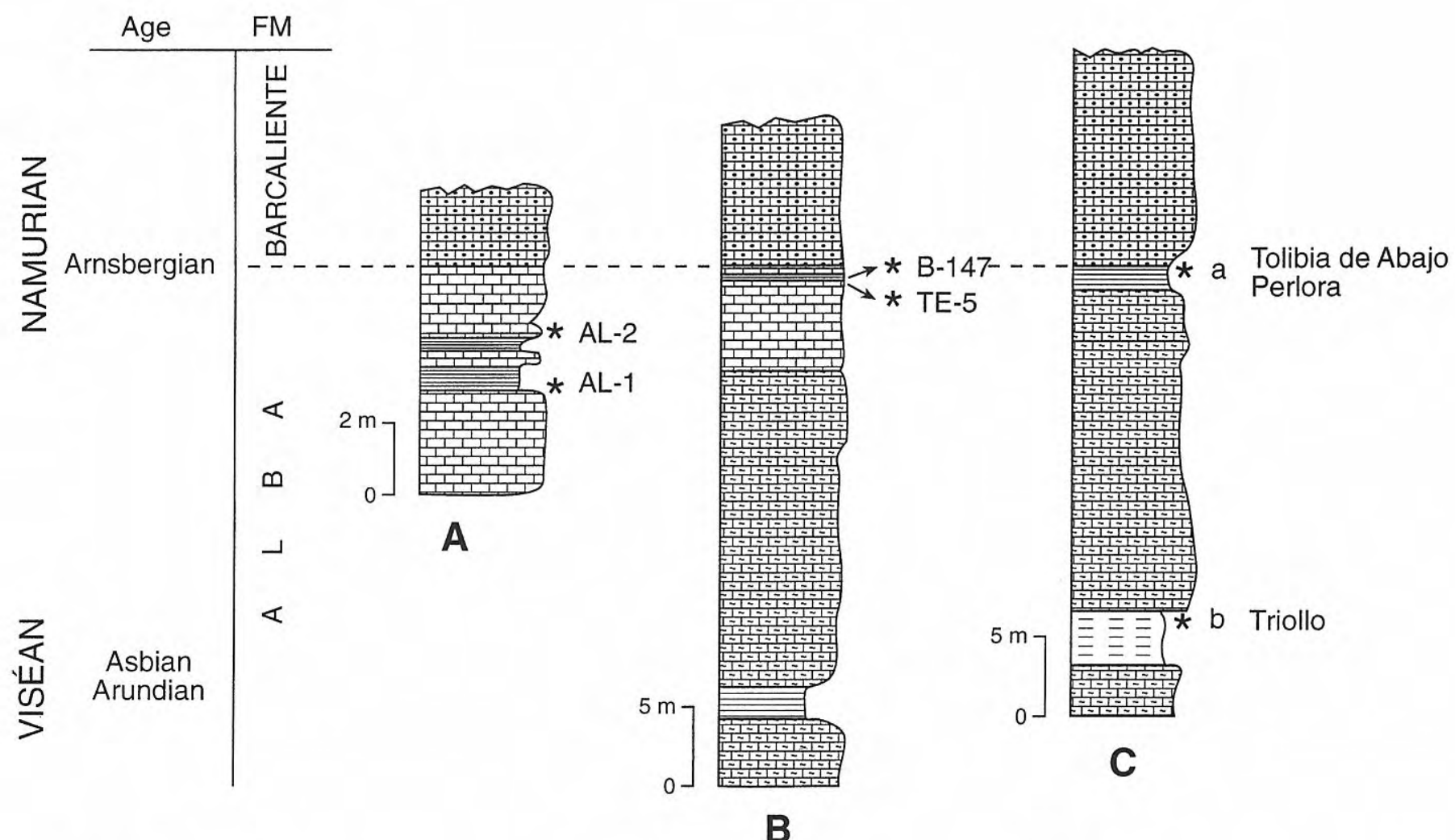

dark grey limestones

reddish greenish marls

red nodular limestones

light grey-beige limestones

三三 chert

Figure 2. Position of the samples in the stratigraphic columns. A: Los Alfilorios; B: Tellego (modified from Menéndez Álvarez, 1991); C: generalized column for the Alba and basal Barcaliente formations (modified from Wagner et al., 1972): a - Tolibia de Abajo and Perlora, b - Triollo.

\section{SYSTEMATIC DESCRIPTION}

PHYLUM BRACHIOPODA Duméril, 1806 SUBPHYLUM RHYNCHONELLIFORMEA Williams, Carlson, Brunton, Holmer \& Popov, 1996

CLASS STROPHOMENATA Williams, Carlson, Brunton, Holmer \& Popov, 1996

ORDER PRODUCTIDA Waagen, 1883

SUBORDER PRODUCTIDINA Waagen, 1883

Superfamily PRODUCTOIDEA Gray, 1840

? Family Productellidae Schuchert, 1929

Subfamily Plicatiferinae Muir-Wood \& Cooper, 1960

Tribe Plicatiferini Muir-Wood \& Cooper, 1960, sensu Brunton, Lazarev \& Grant, 1995

Genus Aseptella Martínez Chacón \& Winkler Prins, 1977 * 1977 Aseptella gen. nov. Martínez Chacón \& Winkler
Prins, 18-19.

Type species: Aseptella asturica Martínez Chacón \& Winkler Prins, 1977.

\section{Emended diagnosis}

Rather small, concavo-convex, transversely rectan- gular productid with ornamentation of rugae and concentric lamellae; ephebic specimens bearing a flange. Corpus cavity rather small. Pedicle valve with few, large spines along hinge and in a row on both flanks; brachial valve without spines, but with a few dimples. Pedicle valve interior with spine openings, pustulose, with lanceolate adductor scars separated by a narrow myophragm and enclosed within large rather vague diductor scars; brachial valve interior pustulose, especially anteriorly, with poorly developed brachial ridges given off at an angle of c. $45^{\circ}$, with strong marginal ridges diverging from the hinge and sealing off the ears from the visceral disc, median septum absent or weakly developed in adult specimens, cardinal process internally bilobed, externally quadrilobate.

\section{Discussion}

The original diagnosis is slightly modified in order to include the new species $A$. beetsi, which shows a weakly developed median septum in the brachial valve interior. The description of the type species was based on external and internal moulds of both valves. The finding of specimens with the shell preserved attributed to $A$. asturica (Martínez Chacón, 1990) and to A. beetsi sp. nov., has permitted us to recognize for the genus the 
presence of concentric lamellae, besides the rugae of the original description of A. asturica.

The genus Aseptella was included in his revised subfamily Plicatiferinae by Lazarev $(1990,1992)$ and later attributed to the tribe Plicatiferini by Brunton \& Lazarev (1997, fig. 1, n 93), with which we can concur, although some of the genera included in the tribe by them (e.g. Crossacanthia Gordon and Platyselma Gordon) appear unrelated. The main difference between the Plicatiferini and the Leioproductini (of the Leioproductinae) appears to be a smaller corpus cavity in the former, the continuity of the rugae over the ventral part of the pedicle valve, the absence of a ventral median fold, which is commonly (but not invariably) present in the Leioproductini, and spines occurring rarely on the brachial valve whilst they are absent from the brachial valve in the Leioproductini.

The Plicatiferinae are assigned by Brunton et al. (1995) to the Productellidae, although they are exceptional in having commonly spines along the hinge, a feature more typical for the Productidae, to which the Leioproductinae are assigned. The reasons why these two rather similar subfamilies are assigned to two different families remain unclear and therefore we assign the Plicatiferinae only questionably to the Productellidae. We hope that the new edition of the Treatise will shed new light on this matter.

Aseptella resembles Absenticosta Lazarev, 1991 in the general aspect of the shell, especially the larger forms such as Absenticosta sp. (Lazarev, 1991, pl. IV, fig. 7), which show a row of spines which are larger than the remaining spines on the ears. Absenticosta is distinguished by its ornamentation of somewhat irregular rugae instead of the regular lamellose bands of Aseptella, its brachial valve interior, the larger number of spines on the pedicle valve and the presence of spines on the dorsal valve.

\section{Aseptella asturica Martínez Chacón \& Winkler Prins, 1977}

* 1977 Aseptella asturica Martínez Chacón \& Winkler Prins, 19-21, pl. 4, fig. 3; pl. 8, figs. 4-10; pl. 9, figs. $1-9$; pl. 14, fig. 6.

. 1990 Aseptella asturica Martínez Chacón \& Winkler Prins; Martínez Chacón, 100, pl. I, figs. 29-32.

\section{Diagnosis}

Aseptella species with dorsal median septum absent, except in some juvenile specimens.

\section{Occurrences}

The species is known from shales of the Ricacabiello Formation at numerous localities of eastern Asturias and northern León (Cantabrian Zone; Martínez Chacón et al., 1985; Winkler Prins, unpublished information), of Bashkirian age, and the Cuera Limestones on the coast of eastern Asturias (Martínez Chacón, 1990), also at levels of Bashkirian age.

\section{Aseptella beetsi Winkler Prins \& Martínez Chacón, sp. nov.}

Fig. 3a-1

1996 Aseptella beetsi Winkler Prins \& Martínez Chacón, nom. nud.; Winkler Prins, p.16.

Holotype: A well preserved brachial valve, DPO 31832 (Fig. 3a).

Type locality: Los Alfilorios, AL-2, coordinates $43^{\circ} 17^{\prime} 48^{\prime \prime} \mathrm{N}, 5^{\circ} 55^{\prime} 12^{\prime \prime} \mathrm{W}$ (Fig. 1).

Type horizon: A $20 \mathrm{~cm}$ thick bed of light-grey, marly limestone in the top part of the Canalon Member of the Alba Formation, at c. $2 \mathrm{~m}$ below the base of the Barcaliente Fm.; early Namurian (Arnsbergian) in age (Fig. 2A).

Material: Holotype, 7 brachial valves and 11 pedicle valves (DPO 31832-31845, RGM 293 313-316), from the type locality, AL-2; 2 pedicle valves (DPO 31846, RGM 293 317), from AL-1, Los Alfilorios. One pedicle valve and 2 brachial valves (DPO 31847-31848) from B-147, Tellego. Five brachial valves and 6 pedicle valves (DPO 31849 , RGM 293 301-308) from PC-2, Perlora. One dorsal valve and 3 pedicle valves (RGM 293 309-312) from WP 51, Tolibia de Abajo. One brachial valve (RGM 293 318) from WP 89, Triollo.

Derivatio nominis: The species is dedicated to the late Dr C. Beets, former director of the 'Rijksmuseum van Geologie en Mineralogie' (now incorporated in the 'Nationaal Natuurhistorisch Museum Naturalis'), who supported our co-operation by providing the first author with the necessary means and showing great interest in our results.

\section{Diagnosis}

Small species of Aseptella resembling the type species but in the brachial valve interior with weakly developed median septum and with lateral offshoots when the lateral ridges reach the lateral margins, separating the ears.

\section{Description}

Shell small, concavo-convex, transversely rectangular in young specimens, becoming more elongate in older ones. The greatest width occurs near mid length, the cardinal extremities being nearly rectangular: Corpus cavity rather shallow. The visceral disc of the pedicle valve has steep flanks and is well separated from the slightly convex ears. The ornamentation consists of concentric lamellae and a flange is sometimes preserved. Strong spines occur in a row separating the ears from the visceral disc and in another row along the highest part of the flanks (Fig. 3e, k-1); occasionally some finer spines are observed on the ventral part. The brachial valve is weakly concave with rather large, almost flat ears. The ornamentation consists also of concentric lamellae and the valve may be bordered by a flat flange (Fig. 3d).

The interior of the brachial valve shows strong lateral ridges which diverge from the hinge and continue along the 


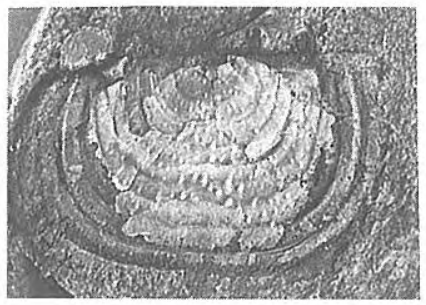

d

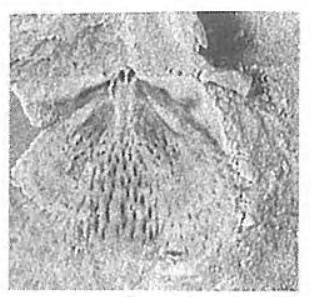

i

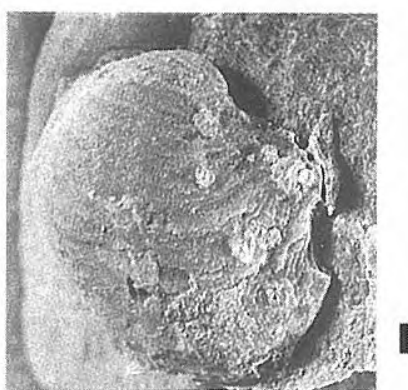

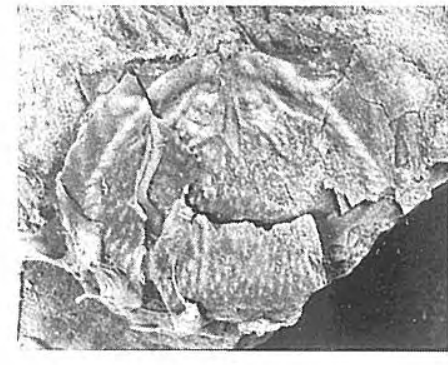

c

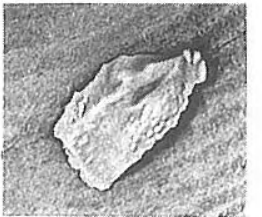

h

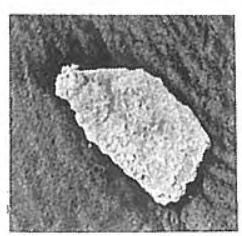

g

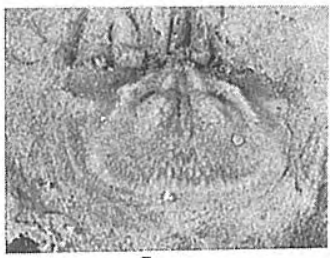

b

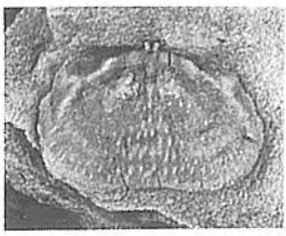

a

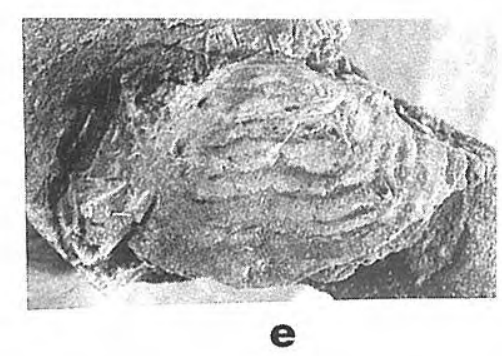

f
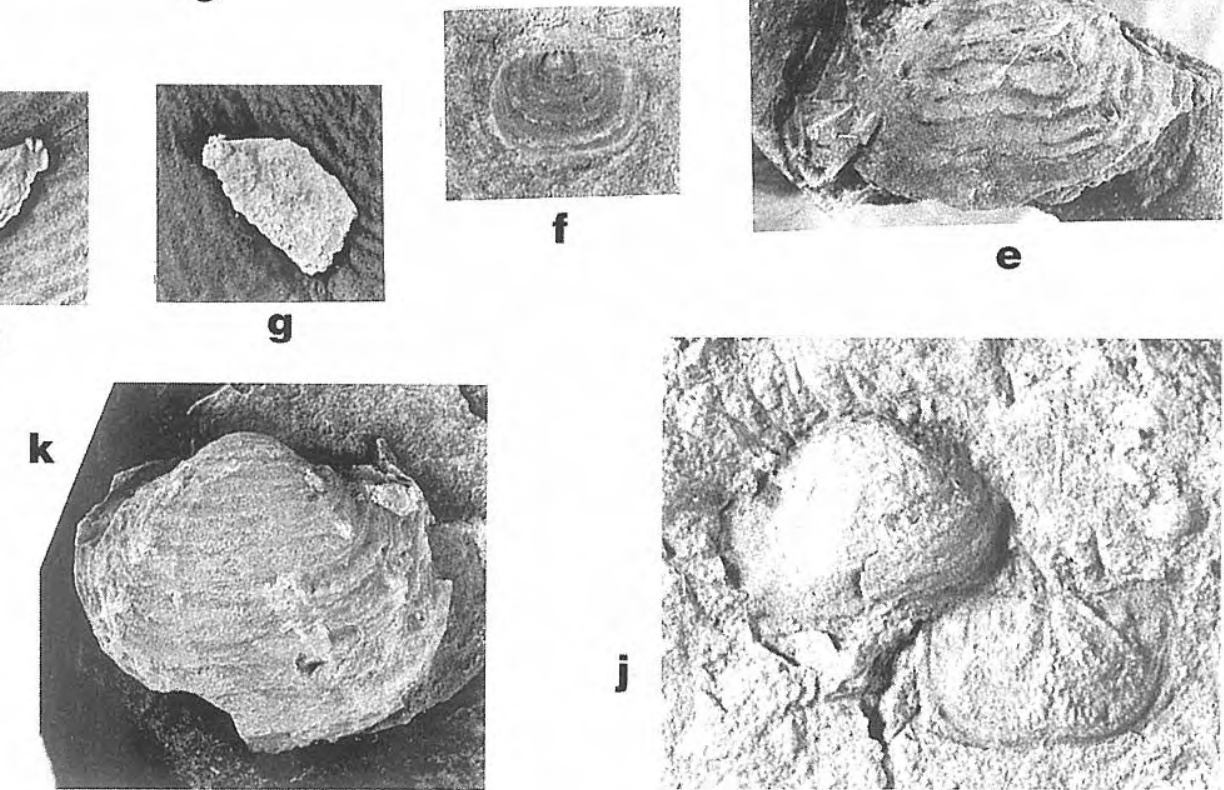

Figure 3. Aseptella beetsi sp. nov. All specimens x5. a. Brachial valve, internal view, holotype, DPO 31832; Los Alfilorios, AL-2. b. Brachial valve, internal view, DPO 31833; Los Alfilorios, AL-2. c. Internal view of a partially broken brachial valve, DPO 31836; Los Alfilorios, AL-2. d. Brachial valve, internal view, DPO 31849; Perlora, PC-2. e. Pedicle valve, DPO 31835; Los Alfilorios, AL-2. f. Brachial valve of a young specimen, DPO 31837; Los Alfilorios, AL-2. g-i. Fragmentary brachial valve exterior, interior and internal mould, DPO 31848; Tellego, B-147. j. Pedicle valve and brachial valve, internal view, DPO 31847; Tellego, B-147. k-l. Pedicle valve: normal view and inclined to show the spines, DPO 31834; Los Alfilorios, AL-2.

lateral margins ending before reaching the anterior margin. When the ridges reach the lateral margin lateral offshoots are formed sealing off the ear regions (Fig. 3a-c, h-i). A median septum is weakly developed between the adductor scars (Fig. 3a-c, j). The brachial areas are covered by small tubercles, with an area bearing bigger and elongated tubercles in between, whilst the ear regions and flange structure are smooth. The cardinal process is internally bilobed and externally quadrilobate.

Measurements (in $\mathrm{mm}$ ):

$\begin{array}{lrrrr}\text { Number } & \text { Length } & \text { Length br. v. Width } & \text { Sample } \\ \text { *DPO 31832 } & & 2.9 & 4.7 & \text { AL-2 } \\ \text { DPO 31833 } & & 3.1 & 4.5 & \text { AL-2 } \\ \text { DPO 31834 } & 6 & & >8 & \text { AL-2 } \\ \text { DPO 31835 } & >4.9 & & 8 & \text { AL-2 } \\ \text { DPO 31836 } & & 5.7 & >8 & \text { AL-2 } \\ \text { DPO 31837 } & & 1.9 & 3.1 & \text { AL-2 } \\ \text { DPO 31838 } & 6.1 & & 9.6 & \text { AL-2 } \\ \text { DPO 31839 } & 5.9 & & 8.3 & \text { AL-2 }\end{array}$

DPO 31840
DPO 31841
DPO 31846
DPO $31847 a$
DPO $31847 b$
DPO 31849
RGM 293301
RGM 293302
RGM 293303
RGM 293304
RGM 293305
RGM 293306
RGM 293307
RGM 293309
RGM 293310
RGM 293311
RGM 293313
RGM 293314
RGM 293315
*Holotype

3.8

5.2

7.3

4.6

2.7

6.9

7

4.6

5.1

AL-2
AL-2
AL-1
B-147
B-147
PC-2
PC-2
PC-2
PC-2
PC-2
PC-2
PC-2
PC-2
WP 51
WP 51
WP 51
WP 84A
WP 84A
WP 84A

AL-2

$>9.2$

$>6.1$ 


\section{Discussion}

The main differences with the type species, $A$. asturica, are the presence in the brachial valve interior of a small, weakly developed median septum (only found in juvenile specimens of A. asturica) and of lateral offshoots of the lateral ridges separating the ears. Also, the flange seems to be less developed in the new species, which could be the immediate ancestor of A. asturica.

The specimen from the griotte limestone at Vallota described by Barrois (1882, p. 290, pl. XIII, fig. 12) as Productus rugatus Phill. has a general resemblance with our new species, but differs in being almost three times larger than our largest specimen and in showing what appear to be spine bases on the median portion of the pedicle valve. Unfortunately, the brachial valve and the internal structures are unknown. We refrain therefore from including it in the synonymy, not even tentatively.

From A. patriciae Simanauskas, 1996 of the Tuberculatella Zone of the Tepuel-Chubut Basin (Argentina) our new species is distinguished by its much smaller size, a smaller flange and the presence of a weakly developed median septum. Although Simanauskas claims his species A. patriciae to be Early Permian (Sakmarian) in age (see also Simanauskas \& Sabattini, 1994), an older, Moscovian?, age cannot be excluded in our opinion since there seems to be little reason to trust the age indicated by the gastropod subgenus Glabrocingulum (Stenozone) more than that indicated by the brachiopod genera Aseptella and Tuberculatella, the latter being known from the Middle Carboniferous to Early Permian (see Waterhouse, 1982; Winkler Prins, 1983). It is interesting to note that to A. patriciae were attributed some specimens found in the Carboniferous (probably slightly younger than Levipustula Zone) from the Calingasta-Uspallata Basin of Argentina (Gabriela Cisterna, person. commun.), which deposits are however considered to be Sakmarian in age by Simanauskas \& Sabatini (1997), mainly on mollusc evidence.

\section{Occurrences}

Aseptella beetsi has been found at various localities in the Cantabrian Mts, in the Alba Formation (see Figs. 1,2) in beds varying in age from Viséan (Arundian-Holkerian) to early Namurian (Arnsbergian). Occasionally complete specimens were found in what could have been their life position (brachial valve upwards). Together with Aseptella a small, restricted fauna is found, which may consist of other small to medium-sized brachiopods, as well as bivalves, trilobites, ostracods, goniatites, and conodonts.

\section{DISCUSSION OF THE GENUS Aseptella}

The Spanish species A. asturica and A. beetsi are both typical of a quiet water environment or Culm facies (Martínez Chacón \& Winkler Prins, 1993). In general these quiet-water faunas of the Cantabrian Mountains are related to the 'Culm' faunas of NW Europe and it is surprising that Aseptella is found only in Argentina instead. Since the quiet-water faunas lived in rather deep, often somewhat muddy seas, which were cooler (less sunlight) and less oxygenated than the carbonate platforms they could more easily cross deep seas and adapt to a cool environment, as found in the Levipustula Zone of Gondwana. The larvae and immature specimens of Aseptella could have been transported entangled in seaweed. The absence of Aseptella in the Culm faunas of northwestern Europe remains puzzling.

The origin of Aseptella is still problematical. The Viséan genera of the Plicatiferini are rather different. Aseptella could have derived from the genus Thomasella of the Institiferini, which is mainly different in having costae on its flange. It should be noted that according to its diagnosis the Institiferini fit better in the subfamily Plicatiferinae than in the Overtoniinae (Brunton et al., 1995, pp. 926-927). The lack of costae in Aseptella could have been caused by the quiet water environment, Thomasella being typical for the Mountain Limestone facies indicating agitated water.

A. beetsi, with its weak median septum in the brachial valve in adult stages of its development, appears to be predecessor of A. asturica, with its median septum only developed in juvenile stage, which could have originated by a process of recapitulation or peramorphosis.

\section{ACKNOWLEDGEMENTS}

The authors wish to thank Dr J. García-Alcalde for providing the first specimens of this new species from the type locality at Los Alfilorios, and Dr S.S. Lazarev for his comments about the material. They are indebted to Dr L.C. Sánchez de Posada for accompanying them in the field and helping to collect the material. They also are grateful to Dr. M. Legrand-Blain (Université de Bordeaux) and Dr. E. Villas (Universidad de Zaragoza) for their constructive criticism which helped us to improve the manuscript. M.L.M.Ch. acknowledges the DGICYT project PB 94-1337 for financial support. The paper is a contribution to the PICG's project 421.

\section{REFERENCES}

Adrichem Boogaert, H.A. van 1967. Devonian and Lower Carboniferous conodonts of the Cantabrian Mountains (Spain) and their stratigraphic application. Leidse Geologische Mededelingen, 39, 129-192.

Barrois, C. 1882. Recherches sur les terrains anciens des Asturies et de la Galice. Mémoires de la Société géologique du Nord, 2 (1), 1-630, pls. 1-20.

Brunton, C.H.C. \& Lazarev, S.S. 1997. Evolution and classification of the Productellidae (Productida), Upper Palaeozoic Brachiopods. Journal of Paleontology, 71, 381-394.

Brunton, C.H.C., Lazarev, S.S. \& Grant, R.E. 1995. A review and new classification of the brachiopod order Productida. Palaeontology, 38, 915-936. 
Comte, P. 1959. Recherches sur les terrains anciens de la Cordillère Cantabrique. Memorias del Instituto Geológico y Minero de España, 60, 1-440.

Evers, H. 1967. Geology of the Leonides between the rivers Bernesga and Porma (Cantabrian Mountains, NW Spain). Leidse Geologische Mededelingen, 41, 83-151.

Gandl, J. 1977. Die Karbon-Trilobiten des Kantabrischen Gebirges (NW-Spanien), 2: Die Trilobiten der AlbaSchichten (Unter-Visé bis Namur A). Senckenbergiana lethaea, 58, 113-217.

Julivert, M. 1971. Décollement tectonics in the hercynian Cordillera of northwest Spain. American Journal of Science, 270, 1-29.

Kullmann, J. 1962. Die Goniatiten der Namur-Stufe (Oberkarbon) im Kantabrischen Gebirge, Nordspanien. Akademie der Wissenschaften und der Literatur in Mainz, Abhandlungen der Mathematisch-Naturwissenschaftlichen Klasse, 6, 1-119.

Kullmann, J. 1963. Die Goniatiten des Unterkarbons im Kantabrischen Gebirge (Nordspanien). II. Paläontologie der U.O. Prolecanitina Miller \& Furnish. Die Altersstellung der Faunen. Neues Jahrbuch für Geologie und Paläontologie, Abhandlungen, 116, 269-324.

Lazarev, S.S. 1990. Evolyutsiya i sistema produktid (Evolution and systematics of the Productida). Trudy Paleontologicheskogo Instituta Akademiya Nauk SSSR, 242, 1-175.

Lazarev, S.S. 1991. Filogeneticheskiy ryad brakhiopod Absenticosta-Impiacus-Lanipustula v Karbone Mongolii. Paleontologicheskiy Zhurnal, 1991 (4), 52-62, pl. 4 (The phylogenetic series of Carboniferous brachiopods Absenticosta-Impiacus-Lanipustula from Mongolia. Paleontological Journal, 25 (4), 65-78).

Lazarev, S.S. 1992. Evolyutsiya i sistema brakhiopod semeystva Plicatiferidae. Paleontologicheskiy Zhurnal, 1992 (1), 44-52 (The evolution and systematics of the brachiopod family Plicatiferidae. Paleontological Journal, 26 (1), 54-64).

Martínez Chacón, M.L. 1990. Braquiópodos carboníferos de la costa E de Asturias (España). I: Orthida, Strophomenida, Rhynchonellida y Athyridida. Revista Española de Paleontología, 5, 91-110.

Martínez Chacón, M.L. \& Winkler Prins, C.F. 1977. A Namurian brachiopod fauna from Meré (Province of Oviedo, Spain). Scripta Geologica, 39, 1-67.

Martínez Chacón, M.L. \& Winkler Prins, C.F. 1993. Carboniferous brachiopods and the palaeogeographic position of the Iberian Peninsula. Comptes Rendus XII International Congress of Carboniferous-Permian Stratigraphy and Geology, Buenos Aires, 1991, 1, 573-580.

Martínez Chacón, M.L., Menéndez-Alvarez, J.R., Sánchez de Posada, L.C. y Truyols, J. 1985. Aportaciones al conocimiento de la Formación Ricacabiello (Carbonífero de la Zona Cantábrica, $\mathrm{N}$ de España) y su contenido paleontológico. Trabajos de Geología, Universidad de Oviedo, 15, 53-65.

Menéndez-Alvarez, J.R. 1991. Conodontos del Carbonífero inferior y medio de la Cordillera Cantábrica. Unpublished Doctor's Thesis, Universidad de Oviedo, 1283,33 pls.

Pérez-Estaún, A., Bastida, F., Alonso, J.L., Marquínez, J., Aller, J., Álvarez Marrón, J., Marcos, A. \& Pulgar, J.A. 1988. A thin-skinned tectonics model for an arcuate fold and thrust belt: the Cantabrian Zone. Tectonics, 7, 517537.

Sánchez de Posada, L.C., Martínez-Chacón, M.L., Méndez, C.A., Menéndez-Alvarez, J.R., Río, L.M., Rodríguez, S., Truyols, J. y Villa, E. 1996. El Carbonífero marino del ámbito Astur-Leonés (Zona Cantábrica): síntesis paleontológica. Revista Española de Paleontología, No Extraordinario, 82-96.

Simanauskas, T. 1996. Un supuesto Chonetoidea del Pérmico de Patagonia reasignado a un género de Productoidea (Brachiopoda). Ameghiniana, 33, 349-351.

Simanauskas, T. y Sabattini, N. 1994. Invertebrados fósiles marinos del Paleozoico superior de Patagonia: implicancias bioestratigráficas y paleogeográficas. Ameghiniana, 31, 395-396.

Simanauskas, T. y Sabattini, N. 1997. Bioestratigrafía del Paleozoico Superior marino de la cuenca Tepuel-Genoa, provincia del Chubut, Argentina. Ameghiniana, 34, 49-60.

Wagner, R.H., Winkler Prins, C.F. \& Riding, R.E. 1972. Lithostratigraphic units of the lower part of the Carboniferous in northern León, Spain (with a Note on some goniatite faunas by C.H.T. Wagner-Gentis). In: The Carboniferous of Northwest Spain. Part 2. (Ed. R.H. Wagner). Trabajos de Geología, Universidad de Oviedo, 4 (1971), 603-663.

Waterhouse, J.B. 1982. New Carboniferous brachiopod genera from Huai Bun Nak, North-east Thailand. Paläontologische Zeitschrift, 56 (1/2), 39-52.

Williams, A., Carlson, S.J., Brunton, C.H.C., Holmer, L.E. \& Popov, L. 1996. A supra-ordinal classification of the Brachiopoda. Philosophical Transactions of the Royal Society London, B, 351, 1171-1193.

Winkler Prins, C.F. 1983. A general review of the Carboniferous brachiopods from the Carboniferous Mountains (North Spain). In: Contributions to the Carboniferous Geology and Palaeontology of the Iberian Peninsula (Ed. M.J. Lemos de Sousa). Anais de la Faculdade de Ciências, Universidade do Porto, 69-91.

Winkler Prins, C.F. 1996. Dr C. Beets (1916-1995) and the 'Rijksmuseum van Geologie en Mineralogie'. Scripta Geologica, 113, 1-21. 